\title{
ROBERT LITWIŃSKI
}

Lublin

\section{OKUPACYJNE LOSY POLICJANTóW \\ W POLSKIEJ HISTORIOGRAFII. STAN BADAŃ I POSTULATY BADAWCZE}

\section{Uwagi wstępne}

Zajmujacc się problematyką udziału policjantów w kampanii wrześniowej oraz ustaleniem ich losów w czasie drugiej wojny światowej, przede wszystkim należy określić podstawowe pojęcia związane z tym zagadnieniem. Po pierwsze uwzględnienia wymaga fakt, że omawiając losy funkcjonariuszy policji, mamy do czynienia z członkami dwóch organizacji policyjnych. Pierwszą z nich była Policja Państwowa (PP), funkcjonująca na terenie piętnastu województw (białostockiego, kieleckiego, krakowskiego, lubelskiego, lwowskiego, łódzkiego, nowogródzkiego, poleskiego, pomorskiego, poznańskiego, stanisławowskiego, tarnopolskiego, warszawskiego, wileńskiego, wołyńskiego) i miasta stołecznego Warszawy. Druga natomiast była autonomiczna Policja Województwa Śląskiego (PWŚl.). Z tego też względu należy zwracać uwage na przynależność policjantów w poszczególnych przypadkach. Czy byli członkami PP czy też PWŚl? ${ }^{1}$

Po drugie, zdefiniowania wymaga pojęcie: „funkcjonariusz policji”. Zadania ściśle związane z wykonywaniem służby bezpieczeństwa były wykonywane zasadniczo przez dwie kategorie osób - oficerów (generalny inspektor, nadinspektor, inspektor, podinspektor, nadkomisarz, komisarz, podkomisarz, aspirant), oraz szeregowych (starszy przodownik, przodownik, star-

1 Szerzej na ten temat zob. R. Litwiński, Policja Państwowa w województwie lubelskim w latach 1919-1939, Lublin 2001. 
szy posterunkowy i posterunkowy) ${ }^{2}$. W przypadku PWŚl. nie występowały stopnie generalnego inspektora i nadinspektora, gdyż główny komendant policji śląskiej był w zasadzie odpowiednikiem komendantów wojewódzkich PP, a te były zastrzeżone dla komendanta głównego PP (generalny inspektor), oraz niektórych wysokich rangą oficerów Komendy Głównej PP (nadinspektor) ${ }^{3}$. W 1936 roku pojawiła się w organizacji policyjnej nowa grupa pracowników - kandydaci kontraktowi. Byli to kandydaci na szeregowych policji, przyjęci do służby przygotowawczej w charakterze pracowników kontraktowych. Rozpoczynano ją w momencie podpisania umowy, a czas służby liczony był od momentu rzeczywistego jej objęcia. Zaliczano ją do wysługi emerytalnej, gdy kandydat przechodził do służby stałej. Podobnie jak etatowych funkcjonariuszy, obowiązywała ich wierność Rzeczypospolitej, posłuszeństwo wobec przełożonych, uszanowanie starszych stopniem służbowym, poszanowanie prawa, gorliwość, sumienność w wykonywaniu obowiązków i zachowanie tajemnicy służbowej. Podlegali służbowo wyłącznie przełożonym policyjnym, przy czym wszyscy oficerowie i szeregowi byli starszymi stopniem w stosunku do kandydatów kontraktowych. Po przesłużeniu co najmniej trzech miesięcy w służbie przygotowawczej, osoby posiadające odpowiednie kwalifikacje, mogły być w miarę wolnych etatów mianowane posterunkowymi. Co prawda nie stanowili pełnoprawnych członków korpusu, ale podlegali przepisom policyjnym, w tym Tymczasowej Instrukcji służbowej dla PP, i uczestniczyli w realizacji zadań związanych z zapewnieniem bezpieczeństwa i porządku publicznego. Nie obciążali przy tym etatu policyjnego, gdyż wchodzili w skład specjalnego kontyngentu osobowego resortu spraw wewnętrznych ${ }^{4}$.

2 Rozporzadzenie Prezydenta Rzeczypospolitej z dnia 6 marca 1928 r. o Policji Państwowej, „Dziennik Ustaw Rzeczypospolitej Polskiej” (dalej: „DzURP”), 1928, nr 28, poz. 257.

3 Rozporzadzenie Prezydenta Rzeczypospolitej z dnia 28 października 1933 r. o stużbie w Policji Województwa Ślaskiego, „DzURP”, 1933, nr 86, poz. 662; por. J. Jeziorski, Nowe rozporzadzenie o stużbie w Policji Wojew. Ślaskiego, w: Kalendarzyk Policji Województwa Ślaskiego 1934, pod red. J. Jeziorskiego, Mikołów b.d.w., s. 173.

4 Rozporządzenie z 16 V 1936 roku stwierdzało, że kandydaci mogli być rekrutowani w ramach etatu PP lub też w ramach dodatkowego kontyngentu wyznaczonego przez MSW, zob. Rozporzadzenie Ministra Spraw Wewnętrznych z dnia 16 maja 1936 r. o warunkach stużby przygotowawczej $i$ zasadach odpowiedzialności stużbowej kandydatów na szeregowych PP, przyjętych do stużby przygotowawczej w charakterze pracowników kontraktowych, „DzURP”, 1936, nr 52, poz. 376; Najprawdopodobniej jednak byli oni przydzielani jedynie w ramach wspomnianego kontyngentu, zob. Kronika, „Przegląd Policyjny", 1936, nr 3, s. 256; W przypadku województwa śląskiego kandydaci znajdowali się natomiast na etacie PWŚl., zob. Rozporzadzenie Ministra Spraw Wewnętrznych z dnia 
Odrębną kategorię pracowników w policji stanowili urzędnicy i niżsi funkcjonariusze do czynności pomocniczych (służba niższa), a więc gońcy, woźni, szoferzy itp. Pod względem formalnym podlegali oni przepisom zawartym w ustawie o państwowej służbie cywilnej, a nie instrukcjom dotyczącym funkcjonowania PP i PWŚl. Natomiast pod względem służbowym i osobowym zostali podporządkowani przełożonym policyjnym. Wobec niższych funkcjonariuszy do czynności pomocniczych i urzędników kancelaryjnych od XII do X stopnia służbowego włącznie, miały zastosowanie przepisy o mianowaniu, przenoszeniu i rozwiązaniu stosunku służbowego dotyczące szeregowych policji, a do pozostałych urzędników kancelaryjnych - takie same przepisy dotyczące oficerów. Urzędnicy w jednostkach policyjnych wykonywali czynności związane z prowadzeniem kancelarii, a więc prowadzili dziennik korespondencyjny, załatwiali ekspedycje pism, zajmowali się sprawami gospodarczymi. Formalnie nie byli więc funkcjonariuszami policji. Uznać ich należy za aparat wspomagający pracę organizacji bezpieczeństwa publicznego ${ }^{5}$.

Po trzecie, pojawia się problem z klasyfikowaniem rezerwistów Wojska Polskiego (WP), przydzielonych przed wybuchem wojny do wsparcia policji, a tworzących pewnego rodzaju służbę pomocniczą. Istnieje pewne prawdopodobieństwo, którego nie można wykluczyć, że w niektórych przypadkach zostali określeni przez władze radzieckie jako policjanci (szczególnie wówczas, gdy używano określenia „rezerwista policji”), a przecież faktycznie nimi nie byli.

Reasumując należy zaznaczyć, że grono policjantów składało się z oficerów, szeregowych i kandydatów kontraktowych. Zaliczymy do nich również osoby określane w materiałach archiwalnych jako „wywiadowcy”, a więc pracowników służby śledczej. Gdyż to właśnie te kategorie wykonywały zadania sensu stricte policyjne i podlegały wszelkim przepisom dotyczacym funkcjonowania policji w II Rzeczypospolitej. Wreszcie jedynie ich dotyczą dane liczbowe funkcjonujące w literaturze przedmiotu, określające stan osobowy policji. Nie byli więc policjantami urzędnicy, niżsi funkcjonariusze do

10 maja 1938 r., o warunkach stużby przygotowawczej $i$ zasadach odpowiedzialności stużbowej kandydatów na szeregowych Policji Województwa Ślaskiego przyjętych do stużby przygotowawczej w charakterze pracowników kontraktowych, „DzURP”, 1938, nr 38, poz. 322; Stużba przygotowawcza w policji, „Gazeta Polska”, 1936, nr 111, s. 3.

5 Rozporzadzenie Prezydenta Rzeczypospolitej z dnia 6 marca 1928 r. o Policji Państwowej, „DzURP”, 1928, nr 28, poz. 257; por. Rozporzadzenie Prezydenta Rzeczypospolitej z dnia 28 października 1933 r. o służbie w Policji Województwa Ślaskiego, „DzURP”, 1933, nr 86, poz. 662 . 
czynności pomocniczych (woźni, gońcy itp.), ani też „agenci policyjni”, gdyż było to określenie osoby udzielającej policji informacji, a więc konfidenta czy informatora, a nie pracownika organizacji bezpieczeństwa publicznego.

Po czwarte, problematyczny jest punkt wyjścia, czyli stan faktyczny funkcjonariuszy we wrześniu 1939 roku. Na przykład w swym raporcie komendant główny PP Kordian Zamorski podaje liczbę 27000 policjantów oraz 30000 rezerwistów WP przydzielonych do wsparcia policji. Jest to jednak informacja błędna, gdyż na podstawie dostępnych danych archiwalnych (między innymi raportów liczbowych poszczególnych komend wojewódzkich sporządzonych pierwszego dnia wojny) wiadomo, że PP 1 września liczyła 29490 policjantów oraz 1284 kandydatów kontraktowych w oddziałach rezerwy policyjnej (razem 30774 osób). Po dodaniu rezerwistów WP (których jednak w żaden sposób nie można potraktować jako policjantów) daje to liczbę 60774 osób $^{6}$. Natomiast w szeregach PWŚl. służyło 3038 oficerów i szeregowych oraz 390 kandydatów kontraktowych 7 . W sumie możemy więc uznać, że do grona funkcjonariuszy policji zaliczymy ogółem 34202 osoby (bez uwzględniania wspomnianych rezerwistów WP).

6 Instytut Polski i Muzeum im. gen. Sikorskiego w Londynie, sygn. A. 43/12, (sbr), Raport z czynności K. Zamorskiego na stanowisku Komendanta Głównego PP w czasie od dnia 11 sierpnia do dnia 18 września 1939 roku dla Ministra Spraw Wojskowych w Paryżu, Baile Herculane 9 XI 1939 roku; por. AAN, Komenda Główna Policji Państwowej - dopływy, sygn. 177, k. 19, sygn. 312, k. 1. Gen. insp. PP, gen. bryg. WP Kordian Józef Ignacy Zamorski, urodzony 1 IV 1890 roku w majątku Kołówka, później nazwanym Rzepienikiem Biskupim w powiecie gorlickim. W sierpniu 1914 roku wstąpił do Legionów Polskich. Po kryzysie przysięgowym w Legionach został przeniesiony do służby w armii austriackiej. Po zwolnieniu został komendantem POW obwodu krakowskiego. 1 XI 1918 roku Zamorski awansowany do stopnia kapitana rozpoczął służbę w Wojsku Polskim. 5 VI 1926 roku objął obowiązki szefa Dep. I (Piechoty) MSWojsk. Z kolei 21 VI 1927 roku powierzono mu stanowisko szefa Oddziału I Szt. Gen. Od 15 XII 1929 roku pełnił obowiązki zastępcy szefa Szt. Gł. Kolejnym etapem kariery wojskowej Zamorskiego było mianowanie go generałem brygady ze starszeństwem od 1 I 1931 roku. 1 II 1932 roku wyznaczony został na zastępcę szefa Szt. Gł. 25 I 1935 roku zwolniono go z zajmowanego stanowiska i przeniesiono w stan nieczynny, z jednoczesnym oddelegowaniem do dyspozycji ministra spraw wewnętrznych. Objął następnie stanowisko kmdta gł. PP, które pełnił do września 1939 roku. Po 1945 roku osiadł w Wielkiej Brytanii. 11 XI 1966 roku awansowany został do stopnia generała dywizji. Zmarł 19 XII 1983 roku w Londynie. Zob. Teczka osobowa K. J. Zamorskiego, AAN, Ministerstwo Spraw Wewnętrznych - dopływy (dalej: MSW dopływy), sygn. 169, k. 1-28; por. P. Stawecki, Stownik biograficzny generałów Wojska Polskiego 1918-1939, Warszawa 1994, s. 362-363; Komendanci Gtówni PP 1919-1939, pod red. K. Filipowa, Białystok 1997, s. 55-61.

7 Ustawa Skarbowa na rok administracyjny 1939/40 z 28 III 1939 r., „Dziennik Ustaw Śląskich", 1939, nr 11, poz. 28. 


\section{Stan badań}

Porównując chociażby działalność policji w czasie wojny polsko-bolszewickiej w latach 1919-1920 i kampanii wrześniowej w 1939 roku, należy podkreślić przede wszystkim ogromną dysproporcję w zachowanych materiałach archiwalnych i wspomnieniowych, na niekorzyść tego drugiego konfliktu. Przyczyną tego była przede wszystkim sytuacja polityczna w Polsce po 1945 roku. Stosunek władz komunistycznych do przedwojennego aparatu państwowego (w tym do Policji Państwowej i Policji Województwa Śląskiego) był jednoznacznie negatywny. Policjantów zaszufladkowano wręcz do grupy „sanacyjnego aparatu ucisku”. Dlatego też nie dziwi fakt, że również sami funkcjonariusze, jeżeli pisali wspomnienia z kampanii wrześniowej, przeznaczali je tylko dla swoich najbliższych, którzy tego rodzaju materiały skrzętnie skrywali w domowych zbiorach. Sytuację komplikował również brak dostępu nie tylko do materiałów archiwalnych przechowywanych na terenie ZSRR (a następnie Białorusi, Rosji i Ukrainy), ale również znajdujących się w Centralnym Archiwum Ministerstwa Spraw Wewnętrznych w Warszawie ${ }^{8}$. Dopiero od lat dziewięćdziesiątych możemy mówić o początkach rzetelnych badań nad dziejami organizacji policyjnych funkcjonujących w II Rzeczypospolitej. Pojawiła się wówczas także możliwość wykorzystania interesujących materiałów, skrzętnie skrywanych do tej pory, a znajdujących się w domowych archiwach byłych policjantów oraz członków ich rodzin.

Przełomowym momentem było przede wszystkim udostępnienie niektórych materiałów przechowywanych na terenie byłego ZSRR, między innymi w Narodowym Archiwum Republiki Białorusi, Państwowym Archiwum Służby Bezpieczeństwa Ukrainy i Państwowym Archiwum Federacji Rosyjskiej - stanowiących podstawe prac:

1. Zachodnia Białoruś 17 IX 1939 - 22 VI 1941, t. 1, Wydarzenia i losy ludzkie. Rok 1939, pod redakcją Bernadetty Gronek, Galiny Knatko i Małgorzaty Kupieckiej, Warszawa 1998.

2. Zachodnia Białoruś 17 IX 1939 - 22 VI 1941, t. 2, Deportacje Polaków z pótnocno-wschodnich ziem II Rzeczypospolitej 1940-1941, pod redakcją Bernadetty Gronek i Grzegorza Jakubowskiego, Warszawa 2001.

8 Przykładem moga być chociażby akta byłych funkcjonariuszy PP zawierające wyniki prac komisji rehabilitacyjnej dla b. policjantów, działającej przy Prezydium Rady Ministrów w latach 1946-1952. W 1989 roku przekazano je do Archiwum Akt Nowych w Warszawie, ale do tej pory zbiór ten nie został w pełni opracowany. Z tego względu korzystanie z niego jest niezmiernie utrudnione, zob. AAN, Akta byłych funkcjonariuszy Policji Państwowej, Korpusu Ochrony Pogranicza, Straży Granicznej i Straży Więziennej 1946-1952 (referat), oprac. Eugenia Szymczuk (1992 rok). 
3. Katyń. Dokumenty zbrodni, t. 1, Jeńcy nie wypowiedzianej wojny. Sierpień 1939 - marzec 1940, pod redakcją Wojciecha Majerskiego, Bolesława Woszczyńskiego i in., Warszawa 1995.

4. Katyń. Dokumenty Zbrodni, t. 2, Zagłada. Marzec - czerwiec 1940, pod redakcją Wojciecha Majerskiego, Bolesława Woszczyńskiego i in., Warszawa 1998.

5. Katyń. Dokumenty zbrodni, t. 3, Losy ocalatych. Lipiec 1940 - marzec 1943, pod redakcją Wojciecha Majerskiego, Bolesława Woszczyńskiego i in., Warszawa 2001.

Istotne są również materiały z Archiwum Prezydenta Federacji Rosyjskiej oraz z Centralnego Archiwum Federalnej Służby Bezpieczeństwa Federacji Rosyjskiej - opublikowane w pracy Deportacje obywateli polskich z Zachodniej Ukrainy i Zachodniej Białorusi w 1940 roku, Warszawa - Moskwa 2003.

Dostęp do tego rodzaju materiałów miał kapitalne znaczenie. Umożliwił przede wszystkim weryfikowanie liczby osób represjonowanych przez władze radzieckie. Na uwagę zasługuje również Ukraiński ślad Katynia, oprac. Zuzanna Gajowniczek, Warszawa 1995, oraz praca przygotowana przez Zuzannę Gajowniczek i Bernadettę Gronek pt. Naznaczeni piętnem Ostaszkowa. Wykazy jeńców obozu ostaszkowskiego i ich rodzin, Warszawa 2000. Materiały źródłowe dotyczące polskiego podziemia na ziemiach zagarniętych przez ZSRR znajdują się ponadto w wydawnictwie pt. Polska $i$ Ukraina w latach trzydziestych-czterdziestych XX wieku. Polskie Podziemie 1939-1941, t. 1, Lwów - Kołomyja - Stryj - Złoczów, pod redakcją Zuzanny Gajowniczek i in., Warszawa - Kijów 1998. Dotyczą one między innymi spraw starszego posterunkowego PP z Oleska Łukasza Widawskiego i starszego przodownika PP ze Lwowa Zdzisława Wróblewskiego ${ }^{9}$.

Poza tym ogromne zasługi posiada Ośrodek Karta, zajmujący się gromadzeniem relacji oraz opracowywaniem poszczególnych tomów Indeksu represjonowanych, gdzie występują nazwiska funkcjonariuszy PP i PWŚl. (m.in. Rozstrzelani w Katyniu. Alfabetyczny spis 4410 jeńców polskich z Kozielska rozstrzelanych w kwietniu-maju 1940, wedtug źródet sowieckich, polskich $i$ niemieckich, pod redakcją Marii Skrzyńskiej-Pławińskiej, Warszawa 1995; Rozstrzelani w Twerze. Alfabetyczny spis 6314 jeńców polskich z Ostaszkowa rozstrzelanych w kwietniu-maju 1940 i pogrzebanych w Mied-

9 Polska i Ukraina w latach trzydziestych-czterdziestych XX wieku. Polskie Podziemie 1939-1941, t. 1, Lwów - Kołomyja -Stryj - Złoczów, pod red. Z. Gajowniczek i in., Warszawa - Kijów 1998, s. 120-137 i 264-279. 
noje, wedtug źródet sowieckich i polskich, pod redakcją Marii Skrzyńskiej-Pławińskiej, Warszawa 1997, Jeńcy w Griazowcu i Suzdalu. Alfabetyczny wykaz 3640 jeńców wojennych z 1939 roku - Polaków i przedwojennych obywateli polskich innych narodowości - przetrzymywanych w sowieckich obozach w Griazowcu i Suzdalu, pod redakcją Ewy Rybarskiej, Warszawa 1998).

Ze względu na poniesione po 1 września konsekwencje, policjantów możemy podzielić na kilka grup:

1. Funkcjonariusze, którzy ponieśli śmierć w wyniku działań wojennych

a) ze stroną niemiecką;

b) ze strona radziecką;

c) w starciach z przedstawicielami mniejszości narodowych.

2. Funkcjonariusze, którzy pozostali na obszarach kontrolowanych przez najeźdźców i ponieśli związane z tym konsekwencje.

3. Funkcjonariusze, którzy opuścili teren państwa polskiego

a) na Węgry;

b) do Rumunii;

c) na Litwę;

d) na Łotwę.

Należy podkreślić, że funkcjonujące dotychczas dane odnoszące się do strat policji w czasie drugiej wojny światowej, są jedynie danymi przybliżonymi. Poza tym przytaczający je autorzy nie podają źródeł tych szacunków. $\mathrm{Z}$ tego też względu można uznać je jedynie za punkt wyjścia do dalszych badań. Szacuje się, że w wyniku bezpośrednich działań wojennych oraz dokonywanych mordów śmierć poniosło około 2 500-3 000 funkcjonariuszy. Ginęli oni przede wszystkim w miejscach pełnienia służby lub w trakcie ewakuacji. Przyjmuje się, że w trakcie obrony samej Warszawy zginęło około 100 policjantów. Do grupy tej zaliczyć można również ofiary działań przedstawicieli mniejszości narodowych, głównie ukraińskiej, na obszarze Małopolski Wschodniej. Ponad 10000 funkcjonariuszy znalazło się na obszarze okupacji niemieckiej. Konsekwencją tego był zastosowany wobec nich nakaz służby w Policji Polskiej (tzw. granatowej) na terenie Generalnego Gubernatorstwa. Według dotychczasowych danych do niewoli radzieckiej dostało się około 12000 policjantów, którzy w zdecydowanej większości nie powrócili do kraju. W Tarnopolu w ręce Armii Czerwonej wpadł transport kolejowy KGPP oraz kilka transportów PWŚl. Szacuje się, że w ręce rosyjskie dostało się w tym mieście około 1400 funkcjonariuszy śląskiej policji, zakwaterowanych w tamtejszych koszarach. Zdecydowanie lepiej los obszedł się z funkcjonariuszami (około 3000 osób), którym w czasie kampanii wrześniowej udało się opuścić granice kraju. Jednak nawet w tej grupie losy były zróż- 
nicowane. W najlepszym położeniu znaleźli się ci, którzy przedostali się na Węgry i do Rumunii. Natomiast około 2000 funkcjonariuszy, którzy zostali internowani na Litwie i Łotwie, po aneksji państw nadbałtyckich dostało się do niewoli radzieckiej ${ }^{10}$. Widzimy więc, że te dane nie zbliżają się nawet do stanu faktycznego policjantów.

\section{Pod okupacją niemiecką}

Wspomniana sytuacja polityczna w Polsce po 1945 roku sprawiła, że problematyka policyjna związana z latami wojny i okupacji nie cieszyła się zbyt dużym zainteresowaniem historiografii. Poza tym, jeżeli odniesiemy się do powyższej klasyfikacji losów policjantów w czasie drugiej wojny światowej, to możemy zaobserwować, że przynajmniej do lat dziewięćdziesiątych $\mathrm{XX}$ wieku, poruszano przede wszystkim problem funkcjonariuszy Policji Polskiej (granatowej), znajdującej się w systemie niemieckiej policji porządkowej na terenie Generalnego Gubernatorstwa. Wymienić w tym miejscu należy przede wszystkim prekursora tych badań Marka Gettera, autora takich artykułów jak: Policja granatowa w Warszawie 1939-1944, [w:] Warszawa lat wojny i okupacji, t. II, Warszawa 1972; Policja Polska w Generalnym Gubernatorstwie 1939-1945, „Przegląd Policyjny”, 1999, nr 1/2, s. 74-91; Przymusiński Franciszek August (Augustyn), [w:] Polski Stownik Biograficzny, t. XXIX, Wrocław - Warszawa - Kraków - Gdańsk - Łódź 1986, s. $214-216$.

Na uwage zasługują również inne prace. Na przykład Jana Popławskiego (Szkolenie policji polskiej Generalnego Gubernatorstwa w okresie okupacji niemieckiej w Polsce, „Przegląd Kryminalistyki”, 1983, nr 162, s. 714-721), Sebastiana Piątkowskiego, opisującego Policję Polską na terenie powiatu radomskiego (Policja Polska tzw. granatowa w Radomiu i powiecie radomskim (1939-1945), „Między Wisłą a Pilicą”, 2001, t. 2, s. 107-128), czy Grażyny Korneć, omawiającej funkcjonowanie podziemnej policji w powiecie siedlec-

10 A. Hempel, Pogrobowcy klęski. Rzecz o policji „granatowej” w Generalnym Gubernatorstwie 1939-1945, Warszawa 1990, s. 30, 91-92; H. Piskunowicz, Policja Państwowa we wrześniu 1939 roku, „Gazeta Policyjna”, 1991, nr specjalny, s. 12; A. Misiuk, Policja Państwowa 1919-1939. Powstanie, organizacja, kierunki działania, Warszawa 1996, s. 340; P. Majer, Okupacyjne i powojenne losy polskich policjantów, „Przegląd Policyjny”, 1999, nr 1-2, s. 103; J. Tucholski, Dzieje zbrodni, „Gazeta Policyjna”, 1991, nr specjalny, s. 6-8; por. О. Гайдай, Б. Хаварівський, В. Ханас, Предтеча. Польський рух Опору на Тернопільшині 1939-1941 рр., Тернопіль 2002, сс. 40-49. 
kim (Policja Podziemna w powiecie siedleckim w latach 1939-1944, „Szkice Podlaskie", 2002, z. 10, s. 123-137).

Najpełniejszym jednak i podstawowym opracowaniem, dotyczącym Policji Polskiej w latach 1939-1944 sa prace Adama Hempla (Policja granatowa w okupacyjnym systemie administracyjnym Generalnego Gubernatorstwa 1939-1945, Warszawa 1987; Pogrobowcy klęski. Rzecz o policji „granatowej" w Generalnych Gubernatorstwie 1939-1945, Warszawa 1990). Autor w wyczerpujący sposób przybliżył genezę i formowanie polskiej służby policyjnej pod okupacją niemiecką, omówił organizację polskich organów policyjnych w Generalnym Gubernatorstwie, ich rolę w realizacji niemieckiej polityki okupacyjnej, współpracę z ruchem oporu, oraz relacje z polskim społeczeństwem.

Uzupełnieniem tej problematyki mogą być wspomnienia przedwojennego policjanta i funkcjonariusza Policji Polskiej Tadeusza Krasnodębskiego, represjonowanego po wojnie przez Służbę Bezpieczeństwa ${ }^{11}$, czy Leona Błażeja Zwolińskiego (Pamiętnik spod strzechy, b.m.w., [2005]).

W kręgu badań dotyczących organizacji policyjnych funkcjonujących pod niemiecką kontrolą można umieścić również pracę Aldony Podolskiej, w której autorka przybliżyła organizację i funkcjonowanie Służby Porządkowej w getcie warszawskim, kierowanej przez przedwojennego podinspektora Policji Państwowej Józefa Szerzyńskiego (Stużba Porzadkowa w getcie warszawskim w latach 1940-1943, Warszawa 1996).

Z okupacją niemiecką są z kolei związane prace poświęcone formacjom porządkowym powstającym pod patronatem władz RP na Uchodźstwie, a więc Państwowego Korpusu Bezpieczeństwa, Straży Samorządowej oraz Straży Obywatelskiej. Na uwagę zasługują w tym miejscu prace Janusza Gmitruka (Policja Polskiego Państwa Podziemnego, „Przegląd Policyjny”, 1999, nr 1/2, s. 74-91) i Janusza Marszalca (Ochrona porzadku i bezpieczeństwa publicznego w Powstaniu Warszawskim, Warszawa 1999).

\section{Pod okupacją radziecką}

Przeobrażenia społeczno-polityczne $\mathrm{w}$ naszym kraju przełomu lat osiemdziesiątych i dziewięćdziesiątych XX wieku, oddziałały w znaczący

11 T. Krasnodębski, O stużbie w szeregach Policji Polskiej Generalnego Gubernatorstwa - ze wspomnień byłego policjanta PP, oprac. P. Majer, „Przegląd Policyjny”, 1997, nr 2, s. 107-116. 
sposób również na rozwój polskiej historiografii. Sukcesywnie, co było związane z uzyskiwaniem dostępu do materiałów archiwalnych dotychczas niedostępnych, pojawiały się możliwości badania nowych problemów. W konsekwencji przede wszystkim szerzej zajęto się udziałem policji w kampanii wrześniowej oraz losami funkcjonariuszy policji pod okupacją radziecką, przy czym istotnych danych (jeżeli chodzi o punkt wyjścia) dostarczyła opracowana przez Adama Moszyńskiego Lista katyńska. Jeńcy obozów Kozielsk, Ostaszków, Starobielsk zaginieni w Rosji Sowieckiej, Warszawa 198912, oraz Jędrzeja Tucholskiego, Mord w Katyniu. Kozielsk, Ostaszków, Starobielsk. Lista ofiar, Warszawa 1991.

Za prekursorów tej problematyki należy uznać naukowców związanych ze środowiskiem policyjnym. Andrzej Pepłoński i Andrzej Misiuk ukazali przygotowania PP do wojny i jej działalność we wrześniu 1939 roku. Wprowadzone przez nich dane o wysokości strat policji funkcjonują do dzisiaj. Niektóre publikacje powstały w dużej mierze na podstawie materiału wspomnieniowego, co wymaga odpowiedniej weryfikacji. Przykładem może być problematyczna kwestia rozstrzelania załogi i uczniów szkoły w Mostach Wielkich w województwie lwowskim. W rzeczywistości nie było tam już wykładowców ani kursantów, gdyż otrzymali nowe przydziały, a kurs wyszkolenia został odwołany jeszcze przed wybuchem wojny ${ }^{13}$. Zbigniew Siemak z kolei przybliżył przygotowania do wojny oraz jej przebieg $\mathrm{w}$ pierwszych 17 dniach na podstawie raportu komendanta głównego PP Kordiana Zamorskiego z dnia 9 listopada 1939 roku $^{14}$. Natomiast Bernard Kayzer zaprezentował mobilizację i działania PWŚl. w okresie zagrożenia wojennego, oraz jej działalność we wrześniu $1939 \mathrm{roku}^{15}$.

12 Książka opracowana przez A. Moszyńskiego ukazała się po raz pierwszy w Londynie w 1949 roku.

13 A. Pepłoński, A. Misiuk, Policja Państwowa we wrześniu 1939 r., w: Zbrodnia katyńska. Droga do prawdy, pod red. M. Tarczyńskiego, Warszawa 1992, s. 38-50; Lista Ostaszkowska. Studia i materiaty, pod red. A. Misiuka, Szczytno 1993, s. 15-16.

14 Z. Siemak, Przygotowania do wojny oraz przebieg jej pierwszych 17 dni w świetle raportu komendanta głównego Policji Państwowej z dnia 9 listopada 1939 roku, w: Polski wrzesień 1939 r. - wojna na dwa fronty, pod red. H. Stańczyka, Piotrków Trybunalski 2000, s. 205-209; por. Policja w kampanii wrześniowej. Raport komendanta głównego Policji Państwowej z 9 listopada 1939 r., w: Losy policjantów polskich po 1 września 1939. Studia i materiaty, pod redakcją P. Majera i A. Misiuka, Szczytno 1996, s. 53-69.

15 B. Kayzer, Mobilizacja i działania Policji Województwa Ślaskiego w okresie zagrożenia wojennego 1939 roku, w: Polski wrzesien 1939 r. - wojna na dwa fronty, pod red. H. Stańczyka, Piotrków Trybunalski 2000, s. 197-202. 
Wartościowe publikacje przygotowywane przez badaczy związanych z Wyższą Szkołą Policji w Szczytnie, a dotyczące losów policjantów pod radziecką okupacją, to między innymi:

1. Lista Ostaszkowska. Studia i materiaty, pod redakcją Andrzeja Misiuka, Szczytno 1993.

2. Losy policjantów polskich po 1 września 1939. Studia i materiały, pod redakcją Piotra Majera i Andrzeja Misiuka, Szczytno 1996.

3. Piotr Majer, Okupacyjne i powojenne losy polskich policjantów, „Przegląd Policyjny", 1999, nr 1-2, s. 102-120.

4. Sławomir Grabowski, Piotr Majer, Ostaszków. Zbrodnia na polskich policjantach, Szczytno 2000.

5. Ostaszków, Twer, Miednoje. Zbrodnia przypomniana, pod redakcją Piotra Majera i Andrzeja Misiuka, Szczytno 2000.

6. Andrzej Misiuk, Instytucje policyjne w Polsce. Zarys dziejów. Od X wieku do wspótczesności, Szczytno 2006.

W konsekwencji problem losów policjantów pod radziecką okupacją zaczął gościć również na łamach publikacji innych autorów. Wymienić można Tomasza Strogulskiego (Granatowa armia, Opole 2000), Ryszarda Wojtkowskiego (Listy proskrypcyjne funkcjonariuszy Policji Państwowej sporzadzone przez NKWD, „Zeszyty Katyńskie”, 1996, nr 6, s. 201-299), Piotra Zawilskiego (Straty osobowe policji państwowej województwa tódzkiego poniesione podczas II wojny światowej na terenach wschodnich II Rzeczypospolitej i na obszarze ZSRR, „Rocznik Łódzki”, 1995, t. 42, s. 209-238), Roberta Litwińskiego (Komisja rehabilitacyjno-kwalifikacyjna dla bytych policjantów (1946-1952), „Dzieje Najnowsze”, 2004, t. 1, s. 117-134).

Interesujące dane znajdujemy również w artykule Tadeusza Pieńkowskiego, omawiającego działania NKWD wobec polskich żołnierzy internowanych po 17 września 1939 roku na terenie Litwy. Przy tej okazji pojawia się również sprawa policjantów (m.in. komisarza Witolda Skrentowskiego, przodowników Kazimierza Fuksa, Pawła Majewskiego, Hilarego Urbanowicza, starszego posterunkowego Konstantego Szydłowskiego i posterunkowego Emila Stefańca), zaginionych po czerwcu 1940 roku na terenie $\mathrm{ZSRR}^{16}$.

16 T. Pieńkowski, Działania NKWD w Zwiazku Sowieckim po czerwcu 1940 r. wobec polskich żolnierzy internowanych po 17 września 1939 r., „Studia z Dziejów Rosji i Europy Środkowo-Wschodniej", 2004, t. XXXIX, s. 263-281. 
Bardzo ważnych informacji, pochodzących przeważnie z domowych archiwów, dostarczyły liczne wydawnictwa przygotowywane przez stowarzyszenie Rodziny Katyńskiej. Znaczna część ośrodków wojewódzkich przygotowała symboliczne listy katyńskie. Wymienić można w tym miejscu:

1. Ryszard Wołągiewicz, Katyń w albumach rodzinnych, Szczecin 1991.

2. Ryszard Wołacgiewicz, Katyń w albumach rodzinnych. Suplement, Szczecin 1993.

3. Mój Ojciec, oprac. Stanisław Maria Jankowski, Kraków 1994.

4. Włodzimierz Jastrzębski, Danuta Rumfeld, Krzysztof Sidorkiewicz, Katyń 1940, Bydgoszcz 1995.

5. Nasi najbliżsi. Katyń, Charków, Twer, oprac. W. Perczak, Toruń 1995.

6. Włodzimierz Jastrzębski, Danuta Rumfeld, Krzysztof Sidorkiewicz, Katyń 1940. Aneks, Bydgoszcz 1997.

7. Lubelska lista katyńska, oprac. A. Winiarz, Lublin 1997.

8. Ocaleni z niepamięci. Losy polskich jeńców wojennych obozów NKWD w Kozielsku, Ostaszkowie i Starobielsku, oprac. Maria Herman i in., Gdańsk 2001.

9. Album Rodzina Policyjna 1939, Katowice [2002], przygotowany przez Stowarzyszenie Rodzina Policyjna 1939 r. w Katowicach.

Pewnego rodzaju podsumowaniem są publikacje Rady Ochrony Pamięci Walk i Męczeństwa, obejmujące listy pochowanych w Charkowie (Charków. Ksiega Cmentarna Polskiego Cmentarza Wojennego, oprac. J. Ciesielski i in., Warszawa 2003), Katyniu (Katyń. Ksiega Cmentarna Polskiego Cmentarza Wojennego, oprac. J. Kiliński i in. Warszawa 2000) i Miednoje (Miednoje. Ksiega Cmentarna Polskiego Cmentarza Wojennego, t. 1-2, Warszawa 2006, oprac. Z. Gajowniczek, B. Gronek, B. Kayzer). Przy czym dla losów policji największe znaczenie ma ta ostatnia. Koncepcja tych wydawnictw była bardzo dobra. Niestety, przynajmniej księge cmentarną Miednoje można uznać za przykład braku szerszej współpracy ze środowiskiem naukowym w kraju. W pracy występują pewne braki, które można było usunąć w wyniku rzetelnej kwerendy w krajowych archiwach. Zdziwienie budzi również brak (przynajmniej w niektórych przypadkach) fotografii policjantów (np. nadkomisarza Bolesława Kusińskiego). Tymczasem można było tego uniknąć na przykład po zapoznaniu się ze zbiorem dotyczącym policji zgromadzonym w Archiwum Dokumentacji Mechanicznej w Warszawie lub po lekturze gazety "Na Posterunku”, gdzie znajdują się fotografie bardzo dobrej jakości. Trudno się zgodzić również z niektórymi stwierdzeniami redaktorów zawartymi we wstępie. O ile rzeczywiście materiał dotyczący Policji Państwowej jest bardzo rozproszony, to nie brakuje akt personalnych 
jej funkcjonariuszy (przynajmniej szeregowych), zgromadzonych między innymi w archiwach krajowych (m.in. Lublin, Bydgoszcz), oraz ukraińskich (Tarnopol, Lwów). Znajdujemy również stwierdzenie, że przeprowadzano kwerendę w archiwach na terenie Rosji, Białorusi, Litwy i Ukrainy. Niestety, nie są one wyszczególnione.

W kręgu problematyki jeniectwa na terenie ZSRR można umieścić również opracowania Mariana Kotarskiego (Przeżył Ostaszków i hitlerowski obóz karny, „Przegląd Policyjny”, 1997, nr 1, s. 93-95), Teofila Mikulskiego (Biogramy jeńców. Kozielsk, Starobielsk, Ostaszków, Ukraina, Zaginieni, Wrocław 1999), Antoniego Rachwała (Przeżyłem Kazachstan. Wspomnienia 1939-1945, Toruń 2003), Stefana Nastarowicza17, czy jeden z działów „Przeglądu Policyjnego" - Epitafia policyjne. Odnotować wreszcie należy fakt ukazania się pierwszej biografii funkcjonariusza policji - Bolesława Kontryma ${ }^{18}$. Można mieć nadzieję, że w najbliższej przyszłości ukażą się kolejne tego rodzaju publikacje.

\section{Zakończenie}

Jak wcześniej wspomniano, losy polskich policjantów w czasie drugiej wojny światowej są zagadnieniem, którego szerokie badanie zapoczątkowano w latach w dziewięćdziesiątych ubiegłego stulecia. Wydaje się jednak, że pomimo zaawansowanych prac, które zostały do tej pory wykonane, stan badań nad tą problematyką nadal jest niezadowalający. W dalszym ciągu posługujemy się jedynie danymi przybliżonymi. Przyczyn takiego stanu rzeczy jest kilka.

Po pierwsze, badania rozpoczęto bez właściwego metodologicznego zdefiniowania podstawowych pojęć, takich jak: członkowie korpusu policji (oficerowie, szeregowi, kandydaci kontraktowi), ich liczebność oraz przynależność służbowa (Policja Państwowa, Policja Województwa Śląskiego).

17 S. Nastarowicz, Moje wrześniowej wojny - 99 dni, mps. (kopia w posiadaniu autora). Wspomnienia te zostały opublikowane, ale w skróconej wersji zob. „Przegląd Policyjny", 1992, nr 4, s. 156-172; Losy policjantów polskich..., op. cit., s. 75-92.

18 W. Pasek, Bolesława Kontryma życie zuchwate. Biografia żolnierza $i$ policjanta 1898-1953, Warszawa 2006. Na ten temat por. Z. Uniszewski, Biografia policyjna $i \dot{z}$ otnierska niewinnie straconego mjr. Bolesława Kontryma Żmudzina (1898-1953), „Przegląd Historyczno-Wojskowy", 2001, nr 3, s. 15-40. 
Po drugie, można odnieść wrażenie, że historycy z kręgów policyjnych zatrzymali się $\mathrm{w}$ pracach badawczych niejako w połowie drogi (jeżeli nie liczyć drukowanych sukcesywnie biogramów na łamach „Przeglądu Policyjnego"), pomimo posiadania stosunkowo bogatych zbiorów. Poza tym gdybyśmy rzetelnie ocenili dotychczasowe publikacje, to można by dojść do wniosku, że kolejne tytuły nie wnoszą nic nowego, a jedynie powtarzają wcześniejsze ustalenia.

Konkludując, należy stwierdzić, że problematyka okupacyjnych losów policjantów wymaga kontynuacji, przy czym oczywiście za punkt wyjścia mogą służyć dotychczasowe ustalenia. Jeżeli chodzi o zasięg ewentualnych prac, można wymienić następujące płaszczyzny badań:

1. Gruntownej kwerendy wymagaja jeszcze liczne materiały zgromadzone w archiwach krajowych (m.in. w Archiwum Akt Nowych), które dotychczas nie były wykorzystywane.

2. Konieczne jest również zapoznanie się z materiałem zgromadzonym w archiwach na terenie Litwy, Białorusi, Ukrainy i Rosji, w tym materiałów byłych służb bezpieczeństwa. Ta ostatnia kwestia wymaga przede wszystkim najpierw kontaktów na szczeblu resortów spraw wewnętrznych Polski i wspomnianych państw, gdyż dotychczasowa praktyka pokazuje, że nie ma innej możliwości skorzystania $\mathrm{z}$ tych wielce interesujących materiałów.

3. Należy dokonać dokładnej kwerendy materiałów zgromadzonych między innymi w placówkach londyńskich: Instytucie Polskim i Muzeum Gen. Sikorskiego, oraz w Instytucie Józefa Piłsudskiego.

4. Przeprowadzenie dokładnego rozpoznania archiwalnego pozwoli na szczegółową konfrontacje z materiałem wspomnieniowym, zebranym od członków rodzin przedwojennych policjantów, co wpłynie jedynie na podniesienie wartości naukowej ewentualnych prac.

Zasięg koniecznych prac pokazuje jednocześnie, że niezbędnym elementem do rozpoczęcia badań nad tą problematyką jest powołanie odpowiednio dużego zespołu badawczego, dobrze zorientowanego w historii Policji Państwowej i Policji Województwa Śląskiego. W ten sposób będą mogły zostać osiągnięte wyniki bazujące na szerokiej podstawie źródłowej.

\section{Occupational lots of police officers in Polish historiography. State of research and research postulates}

\section{Summary}

Comparing the police activity during Polish-Bolshevik War of 1919-1920 and September Campaign of 1939 a huge disproportion in preserved archive materials 
and memoirs should be emphasized, especially those referring to the latter conflict. The reason for this was most of all the political situation in Poland after 1945. The attitude of communistic authorities to prewar State apparatus was unambiguously negative. The situation was further made more complicated by the lack of access not only to the archive materials stored in the USSR (and later in Belarus, Russia and Ukraine), but also to those stored in the Central Archive of the Ministry of Internal Affairs in Warsaw. We can talk about the beginning of reliable research on the history of police organizations operating in the II Republic of Poland only since the 1990s. Above all, a breakthrough occurred when some materials stored within the territory of former USSR, among the others in the National Archive of the Republic of Belarus, the Ukraine State Archive of Security Service and the State Archive of Russian Federation, were disclosed and made available. Despite advanced works that have been done so far, the lots of Polish police officers during World War II still require intensive research. Numerous materials gathered in national archives still require a thorough query, moreover, it is necessary to get acquainted with the material gathered in the archives in Lithuania, Belarus, Ukraine and Russia, including the materials of former Secret Service. A comprehensive query of the materials gathered, among the others, in London institutes, should be made: the Polish Institute, the General Sikorski Museum, and the Joseph Pilsudski Institute.

\title{
Оккупационные судьбы полицейских в польской историографии. Состояние исследований и исследовательские требования
}

\author{
Резюме
}

Сравнивая деятельность полиции во время польско-большевистской войны 1919-1920 и сентябрьской кампании в 1939 г. нужно подчеркнуть прежде всего огромную диспропорцию в сохраненных архивных и мемуарных материалах в ущерб этого второго конфликта. Причиной этого была, в первую очередь, политическая ситуация в Польше после 1945 года. Отношение коммунистических властей к довоенному государственному аппарату было однозначно отрицательным. Ситуацию осложняло тоже отсутствие доступа не только к архивным материалам, хранимых на территории СССР (а затем Белоруссии, России и Украины), но и находящихся в Центральном архиве Министерства Внутренних Дел в Варшаве. Лишь с девяностых годов можно говорить о началах добросовестных исследований истории полицейских организаций, функционирующих в II Речи Посполитой. Переломным моментом стало прежде всего открытие доступа к некоторых материалам, хранимым на территории бывшего СССР, между прочем в Национальном архиве Республики Беларусь, Государственном архиве службы безопасности Украины и Государственном архиве Российской Федерации. Судьбы польских полицейских во время второй мировой войны, несмортя на сильно продвинутые вперед работы, проведенные 
да этого времени, по-прежнему требуют интенсивных исследований. В основательном розыске нуждаются еще многочисленные материалы, собранные в отечественных архивах, необходимо познакомиться с материалами, находящимися в архивах Литвы, Белоруссии, Украины и России, в том числе с материалами бывших служб безопасности. Нужно провести тщательный розыск материалов, собранных в лондонских учреждениях: Польском институте и Музее ген. Сикорского, а также Институте Иосифа Пилсудского. 